\title{
Research on the Basis Theoretical Questions of Environmental Finance
}

\author{
Cai-ping ZHANG ${ }^{\mathrm{a}, *}$ \\ University of South China, Hunan, Hengyang, China, \\ 421001 \\ a871758842@qq.com
}

\author{
Qian-wen WU \\ University of South China, Hunan, Hengyang, \\ China, 421001 \\ b316579634@qq.com
}

\begin{abstract}
Environmental finance is developing as a field in response to an acceptance of the idea that sound environmental management is positively correlated with sound economic management. Thus, there is growing confidence that environmental quality is justified by the bottom line. However, because environmental quality cannot be packaged like a physical commodity and sold in a traditional marketplace, innovation has been required to develop new financial instruments that recognize and reward environmental virtue in the private sector. The paper studies such related problems as the environment management and shareholder value creation, environmental management system, tools of risk management accelerate the development of environmental finance.
\end{abstract}

Keywords-environmental finance; environmental management system; tools of risk management; shareholder value creation

\section{INTRODUCTION}

The rate of societal change has been accelerating since the inception of the industrial revolution. We are now increasingly aware that the negative environmental side effects of that revolution are not trivial. Nor are they insuperable or too costly to contemplate. However, until recently many of these side effects were largely ignored. People may have observed some impacts but they were not systematically managed. Some were the responsibility of the public sector (especially nuclear power, water supply and treatment, and solid waste management) and hence rarely a concern of the private sector. Some of the side effects took years to show up (such as long-tailed insurance claims for asbestos liability), and the insurance industry was totally unprepared to manage the risk. Deregulation-often including the activities of formerly public companies-has now brought these concerns to the private sector. In order to reassure the voters, government has brought in a whole array of new regulations ("regulation") to make the newly privatized operations transparent. Another great force for change has been globalization. Companies have been released from the confines of the regional or national markets and have taken a global stake. The largest companies have been doing this for a hundred years. Now much of the rest of the economy is following. Some newly privatized businesses-like water supply and treatment-find themselves on the global scene for the first time.

Legal redress is becoming globalization. Ironically, this has been possible for a long time, specifically through the U.S.
Humanistic social science young fund of the Ministry of Education(10YJC790366)

Alien Tort Claims Act of 1789,which allows foreign nationals to sue American companies in the American courts. This is now being used by diverse groups around the world to sue American companies for damage to their environments. Even if companies and their financial service providers had ignored these developments, they could not ignore the very tangible costs of a poor environmental performance. These have been heavy. The costs of asbestos, inadequate landfill management, and oil spills have had major impacts on their balance sheets. Such cases will be identified in the rest of this book. Management failures have led to huge insurance payments and, in some circumstances, eventually to bankruptcy. Environmental problems have pitted old partners-such as manufacturers, insurers, and bankers-against one another.

A number of companies now understand this change of paradigm very well and have moved to address it. On the positive side there is increasing evidence that the market rewards proactive environmental management.

\section{ENVIRONMENTAL MANAGEMENT AND SHAREHOLDER VALUE CREATION}

Research attempting to link environmental and financial performance reveals a growing sense that sound environmental management can lead to increased shareholder value, which is defined as: Value for shareholders which is created when a business, over time, uses capital at its disposal to earn returns greater than, or equal to, the cost of that capital (Willis and Desjardins 2001).

Traditionally, environmental management has been seen as imposing a cost on a company and a "green penalty" on investors, with no corresponding benefit being conferred. The opposing view holds that environmental performance is compatible with, and perhaps central to, competitiveness and superior financial performance (Porter and van derLinde, 1995). There is strong evidence that improved environmental behavior has a strong impact on shareholder value (Dowell et al. 2000; Sustainability/UNEP 2001; UBS 2000).

A business case can be made that not only dispels notions that environmental initiatives have an adverse effect on profitability, but holds that they contribute to shareholder value creation. Figure 2.1 demonstrates the linkages between improved corporate environmental performance 
and the creation of shareholder value. Areas of strategic decision making within a company's product management, operations, capital assets, and finance departments govern the processes that create value for the corporation, through their impacts on revenues, operating costs, and the cost of capital. Improved environmental management decisions at this level influence these value drivers, which in turn generate shareholder value. The following discussion demonstrates how a focus on environmental issues can lead to increased revenues, decreased operating costs, and a lower cost of capital.

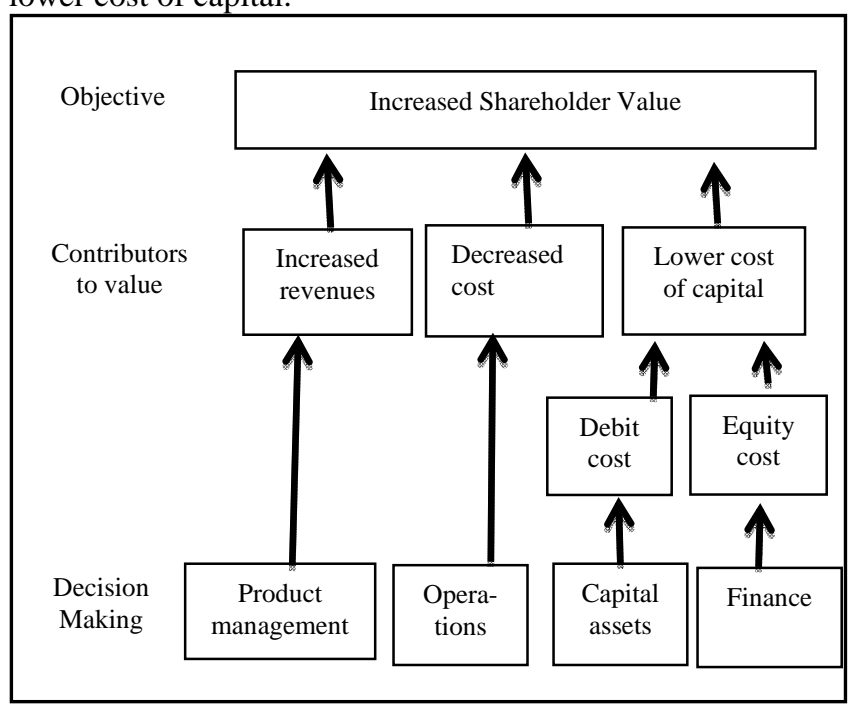

Figure I. Shareholders value creation model.

\section{A. Product Management}

A strong environmental focus in the product design can lead to new product development and, in some cases, can redefine markets (U.S. EPA 2000). Considerations of a product's environmental impacts at the design stage can keep a firm in the forefront of market innovation and position it well to reap marketing advantages. From this marketing standpoint, an environmental focus can help improve a company's revenues as its environmentally improved products are differentiated from others, contributing to increased brand recognition and competitive advantage. From a liability perspective, if a company's product has adverse effects on the environment, the company can bear liabilities that strike at the core of its business.

\section{B. Operations}

In addition to product management and design, many firms' environmental impacts come from their manufacturing processes. Taking environmental considerations into account in these processes can help firms reduce the energy and raw materials inputs, as well as reduce waste outputs. Process changes that reduce environmental impacts can lead to lower costs and increased operational efficiency. Insurance specialists have recognized a reduction in risk for firms with strong operational environmental management. Some insurers have created products that translate improved environmental performance into lower premiums.

\section{Capital Assets}

A focus on environmental issues when making capital asset investment decisions also helps to lower a company's costs. Not only do investments in environmentally appropriate fixed capital assets lower production costs and make the operating process more efficient, they also help to improve a firm's environmental profile. As a result, a firm that has invested in environmentally favorable assets will be well positioned to comply with new environmental regulations, and to increase its ability to use those assets that benefit the environment over their full operating lives. In addition, the firm will be less prone to environmental incidents, which lead to costly cleanup charges and legal liability. Lending institutions take into consideration a company's reduction in environmental risk, in considering favorable lending terms.

\section{Finance}

While increasing revenues and decreasing costs help to improve a firm's income, financing decisions are central to the long-term creation of value in the organization. Financing decisions are crucial to the retention of firm value over time, allowing for expansion or acquisitions as well as having an impact on tax and interest expenses.

A firm's two main choices for raising funds are debt or equity financing, although hybrid instruments do also exist. The cost of capital for a firm is defined in terms of the weighted average of its costs of equity and debt, and reflects the company's marginal costs of raising capital (Damodaran, 2001). Firms with poor environmental management, therefore, can be expected to pay higher rates of interest than others, due to the increased risk of environmental liability in the eyes of its investors. This results in a higher cost of debt and larger debt obligations, thus reducing residual earnings that provide a return to equity holders and destroying shareholder value. Lenders may, indeed, view a certain level of risk as too great, and may not be willing to lend to a firm demonstrating poor environmental management. Studies illustrate that the exposure to Superfund liability can decrease the likelihood of loan approval (Schaltegger and Burritt,2000). Such reticence on the part of lenders can prevent the firm from expanding, and thus stunt the growth of shareholder value. In project financing, lenders will take into account not only the risk level of the firm, but also the perceived risk of the project for which the capital will be used. As a result, aspects of a borrower's environmental profile are used, not only to calculate risk premiums, but also to decide whether a loan for a specific project with a negative environmental impact should be made at all (Blumberg et al. 1997).

\section{III..ENVIRONMENTAL MANAGEMENT SYSTEM (EMS)}

An environmental management system (EMS) is designed to control adverse environmental impacts, just as 
financial management is designed to control a company's economic well-being.

A firm's approach to the development of an environmental management system entails both the formulation of long-term environmental policies and goals as well as the adaptation of current business activities in order to reduce the impacts of the firm's product and process on the environment. Figure 2.2outlines the basic components required for the establishment of a comprehensive EMS. The first phase involves the collection and development of evidence of the need for an environmental policy and strategy, followed by top management's commitment and board approval for new environmental management and reporting strategies. Company specifics such as its mission statement and available budget are significant at this stage. Once the commitment has been obtained and the strategy communicated throughout the company, the next phases involve the development of the policy and programs to be implemented and the development of the management system components. Reporting of an environmental policy statement serves to establish the direction the firm is taking as well as to communicate the plan to employees and the broader public. The sixth stage outlined in Figure 2.2 involves the actual implementation of the plan. As the performance of the EMS is measured, it is also evaluated, with feedback then creating the basis for adjusting the programs and perhaps even adapting the environmental policy. Such feedback implies continual improvement within the EMS framework.

To help the financial services sector meet the requirements of an EMS, a group of British financiers brought out the Forge Report (Forge 2000), which offers practical guidance on the development of an EMS within financial companies. The report pays more attention to the first stage of evidence development and senior management commitment, since financial institutions have historically not seen themselves as a polluting industry.

\section{TOOLS FOR RISK MANAGEMENT}

\section{A. Traditional Insurance Mechanisms}

Insurance will continue to be the principal vehicle for the transfer of business and personal risk. However, there are at least two circumstances in which insurance companies may find themselves unable or unwilling to accept certain risks that they may have covered in the past. First, there is the capacity issue. The magnitude and frequency of major catastrophic losses in the late 1980s and through to the present have challenged the capacity of traditional insurance and reinsurance markets. This was especially true following Hurricane Andrew (in 1992) and becomes an issue again following the destruction of the World Trade Center (in 2001). If the scale and frequency of catastrophes continue to grow, then a wider diffusion of the risk market may become desirable or necessary. This issue is explored in the next subsection.

A more specific issue concerns the types of environmental risk that can be insured. Pollution liability was never intended to be covered by commercial general liability (CGL) policies. Even so, CGL was the door that was opened by the American courts to fund claims for asbestos, lead paint, and Superfund, as well as the accidental spills that it was expected to cover. Attempts to exclude pollution in CGL policies met with mixed success in the American courts. Pollution is now covered by separate environmental policies covering risks associated with asbestos, underground storage tanks, accidental pollution liability, and lead abatement, among others. Special-purpose cover is also provided by specific cleanup cost overruns for remedy polluted building sites.

\section{B. Tapping into the Capital Markets}

In the wake of Hurricane Andrew there was a widespread and rapid reassessment of just what could be insured by the traditional insurance and reinsurance market. Whereas the major companies were well prepared, others were vulnerable. There was a real danger that government (especially the elected insurance commissioners in each state) would step in to force the solvent companies to fill the breach by obliging them to join involuntary pools to provide backup cover, as had happened so often in the past. That point forced some consideration of tapping into the capital markets with their much greater volume of transactions and capital base. Thus began an exploration of various offbalance-sheet instruments to make this transition. New products were developed to mimic derivative instruments that had been appearing since the mid-1970s to hedge risks in the financial markets, principally volatility in foreign exchange and interest rates (Smithson 1998). Options and swaps are the instruments most widely used. In the 1990s catastrophe options were designed to provide a flexible infusion of capacity through the Chicago Board of Trade, based on the insurance losses due to catastrophes in the United States. Swaps based on exposure to extreme weather events, such as heavy rainfall and both high and low temperatures, have proven more durable. There is now a growing "weather market," driven, so far, by large energy companies hedging their volume exposures in a deregulated world. Catastrophe bonds, or "cat bonds," have been developed to bring in additional partners to share the financial risk by going directly to the institutional investors. These bonds have the advantage of being quite simple conceptually, compared with the derivative products described in the previous subsection. The downside is that each bond must be configured for each placement, which takes time and therefore carries a higher transactional cost. The market is growing steadily, so it certainly seems to meet a need. Also, the secondary market in cat bonds is developing quickly, which encourages liquidity in the market and hence further growth.

\section{CONCLUSION}

Environmental finance is developing as a field in response to an acceptance of the idea that sound environmental management is positively correlated with sound economic management. We are no longer tying ourselves to the old assumption that a clean environment is 
bad for profits. Thus, there is growing confidence that environmental quality is justified by the bottom line. However, because environmental quality cannot be packaged like a physical commodity and sold in a traditional marketplace, innovation has been required to develop new financial instruments that recognize and reward environmental virtue in the private sector. All this is happening at a time when our biggest environmental challenge-climate change-is injecting both uncertainty and urgency into the global situation.

We can admit now that the results have been mixed. This is largely because the development of new financial products can happen only if the regulatory framework is there to make it happen. It requires clear rules that charge the polluters for polluting and reward those who enhance the quality of the environment. Once the regulatory framework has been constructed, then market forces have the potential to provide a dynamic motor for improved environmental performance. To meet that potential we need a trading infrastructure that provides transparency for price discovery and liquidity to allow traders to enter and leave markets.

\section{ACKNOWLEDGEMENTS}

The authors would like to thank anonymous reviewers for helpful comments and the China National Social Science Foundation (Grant No.13CGL029) and Hunan Province Education Bureau Key Foundation ( Grant No.16A190) for providing financial support.

\section{REFERENCES}

[1] Willis, A., and J. Desjardins, "Environmental Performance: Measuring and Managing What Matters”,Canadian Institute of Chartered Accountants. Toronto, pp.235-238,2001.

[2] Porter, M., and C. van der Linde,"Green and competitive: Ending the stalemate”, Harvard Business Review,vol. 73(5),pp. 120-134,1995.

[3] Dowell, G., S. Hart, and B. Yeung,"Do corporate global environmental standards create or destroy market value?”,Management Science vol.46(8),pp.1059-1074,2000.

[4] UBS.Environmental Report,Union Bank of Switzerland. Zurich www.ubs.com/environment, 2000

[5] Damodaran, A, Corporate Finance: Theory and Practice,New York: John Wiley \& Sons, 2nd edited,2001.

[6] Schaltegger, S., and R. Burritt,Contemporary Environmental Accounting:Issues, Concepts and Practice. Sheffield, UK: Greenleaf. 2000.

[7] Blumberg, J., G. Blum, and A. Korsvold,Environmental Performance and Shareholder Value, Geneva: World Business Council for Sustainable Development, www.wbcsd.com/ecoeff1.1997

[8] Forge. Guidelines on Environmental Management and Reporting for the Financial Services Sector,London: Forge Group,2000

[9] Smithson, C. W, Managing Financial Risk: A Guide to Derivatives Products, Financial Engineering and Value Maximization. 3rd edited. New York: McGraw-Hill. 1998 